Author's Conrtibution

A - Study Design

B - Data Collection

C - Statistical Analysis

D - Data Interpretation

E - Manuscript Preparation

$\mathrm{F}$ - Literature Search

G - Funds Collection

\section{Training Load Structure of Young Soccer Players in a Typical Training Microcycle during the Competitive and the Transition Period}

\author{
Andrzej Głowacki $i^{(\mathrm{B}, \mathrm{E}, \mathrm{F})}$, Wojciech Ignatiuk ${ }^{(\mathrm{C}, \mathrm{F})}$, \\ Anna Konieczna ${ }^{(A, G)}$, Zbigniew Jastrzębski ${ }^{(B, D, E)}$ \\ Jedrzej Sniadecki Academy of Physical Education and Sport \\ in Gdansk, Poland
}

Key words: training load, load registration, young soccer players

\section{Abstract}

Background: The aims of this study were: (1) to characterize the training load structure and the applied training means in typical microcycles of the transition period and the competitive season administered to young soccer players, and (2) to present exemplary training units of the competitive and the transition periods.

Materials and methods:

20 young soccer players (12-13 years old) took part in the study. Jastrzębski's method based on Sozański and Śledziewski was applied to register and monitor the training load. Data was analyzed regarding the information range (general or specific drills) as well as energetic zones (aerobic, mixed aerobic-anaerobic, anaerobic lactate or anaerobic alactate drills).

Results: $\quad$ The results of study show crucial differences in the applied training means in the analyzed microcycles. In a typical microcycle of the transition period general drills predominate, while during the competitive period - specific drills prevail. The total effective time of training was longer in the competitive season microcycle. It is a proper relationship according to the theory of sport training.

Conclusions: The range of the training load registered in the competitive season is in line with other authors' research where league matches and small-sided games were used particularly often. The studied microcycles in the competitive season can be model ones and can be used in the training process of young football players.

$\begin{array}{lrrr}\text { Word count: } & 2518 & & \\ \text { Tables: } & 8 & \text { Received: } & \text { December } 2010 \\ \text { Figures: } & 3 & \text { Accepted: } & \text { February } 2011 \\ \text { References: } & 19 & \text { Published: } & \text { March } 2011\end{array}$

Address for correspondence

Mgr Andrzej Głowacki, Academy of Physical Education and Sport,

80-336 Gdańsk, Poland, ul. K. Górskiego 1, Phone: +48500131719, e-mail: glowacki86@wp.pl 


\section{Introduction}

The level of soccer skills is dependent on many factors. Technical drills and physical capacity seem to be very important components of a player's competence. Coincident developing of both these capacities is a crucial condition to educate top level soccer players. However, the proportion of technical to physical training is different in individual age groups. The monitoring and analyzing of the training process is an indispensable part of coaching young players. Recording the training load constitutes a very important aspect of this process. It leads to an adequate selection of the means and amount of the training load and, in consequence, efficiency enhancement. The volume and intensity of the training are the primary determinants of the training load. Training volume in sports like soccer is defined as the total duration in minutes or as the number of repetitions of an exercise [1]. The second component of the training load is usually described using heart rates and lactate concentration measures or ratings of perceived exertion (RPE) $[2,3,4,5]$.

Scientific works by Wolkow and Koriagin [6], or Kosendiak and Lasinski [7] gave foundation for the registration of training loads. It is essential to determine practical and valid methods to quantify exercise loads [2]. Actually, Sozański and Śledziewski's [8] method is preferred by soccer trainers. Nevertheless, Jastrzębski [9] presented the modified method to record training loads which is clearer and more accessible. It is difficult to control training intensity at an individual level so a general team training prescription is usually used to determine the training loads $[10,11,12]$. The issue was brought up by Konieczna et al. [13] in order to determine the influence of training loads upon anthropometric values of young players from Football Academy in Malbork. Jastrzębski and Szutowicz [14] examined the influence of a training load upon aerobic and anaerobic efficiency in young Lechia Gdańsk players during their second stage of the training process. Śliwowski et al. [15] studied a group of 22 junior players from WKP Lech Poznań Football Club before and after the basic preparatory period of the 2006/2007 season. The tests used in the assessment of aerobic performance were: PWC 170, the progressive running test to exhaustion and the Multistage Shuttle Run Test (MST) - a shuttle endurance test which allows predicting the maximum oxygen uptake $\left(\mathrm{VO}_{2} \mathrm{max}\right)$.

The aims of this study were: (1) to characterize the training load structure and the applied training means in typical microcycles of the transition period and the competitive season administered to young soccer players, and (2) to present exemplary training units of the competitive and the transition periods.

\section{Material and Methods}

The research was conducted on a sample of 20 soccer players at the age of 12-13 years from LKS "Żuławy" Club in Nowy Dwór Gdański. Each player possessed his personal health record and each one underwent current medical check-up.

Two typical microcycles were chosen for analysis (one of the competitive season: 07-13.09. 2009, and one of the transition period: 16-21.11.2009). Jastrzębski's method [9] was applied to monitor and register the training load. The load was divided into four groups:

1. aerobic (below Anaerobic Threshold; TO - general drills, TS - special drills),

2. mixed aerobic-anaerobic general (MO) and specific (MS) on, or just above Anaerobic Threshold,

3. with the practice longer than 90 seconds, anaerobic-lactate general (BKO) and specific (BKS),

4. anaerobic-non lactate general (BNKO), and specific (BNKS).

The training means were divided into 15 main groups (Tab. 2). According to the author, each coach, based on his practical expertise, defines what kind of load each exercise is. The quality

Tab. 1. Biometric parameters of young soccer players (mean \pm standard deviation)

\begin{tabular}{|c|c|c|c|}
\hline $\begin{array}{c}\text { Age } \\
\text { [years] }\end{array}$ & $\begin{array}{c}\text { Height } \\
{[\mathrm{cm}]}\end{array}$ & $\begin{array}{c}\text { Weight } \\
{[\mathrm{kg}]}\end{array}$ & $\begin{array}{c}\text { BMI } \\
\text { Value }\end{array}$ \\
\hline $12.4 \pm 0.58$ & $152.3 \pm 8.88$ & $41.1 \pm 11.55$ & $17.51 \pm 3.22$ \\
\hline
\end{tabular}


Tab. 2. Training means for soccer players

1. Different forms of general warm-up

2. Different forms of specialist warm-up

3. Relaxing and flexibility exercise and stretching

4. Continuous run

5. Middle length distance run

6. Sprints

7. General fitness drills

8. Coordination drills

9. Strength exercise

10. General fitness exercise in form of different games and additional sports

11. Individual or group technical drills

12. Technical-tactical exercise in defense and attack

13. Small-sided games in different forms

14. League, cup and control games

15. Physical and specific soccer tests

of exercise is determined by one of 15 training means groups. Exercises applied during the tested training units were put in special tables with information on drill types, effective time of exercise $(\mathrm{min})$, total time of exercise $(\mathrm{min})$, energy-information field, drill intensity $(\%)$ and general effectiveness of exercise (\%).

\section{Results}

A typical microcycle in the competitive season was made up of four training units and one league game. (Monday - two units; Wednesday and Friday - one unit, Saturday or Sunday league game). The exercise intensity of each drill was comparable to current recommendations in the literature regarding suitability for soccer training [15].

Three training sessions in a typical microcycle of the competitive season are shown in Tables 3,4 and 5 .

Mixed energy systems exercises developing soccer skills (M.S. 127 minutes) followed by general aerobic drills (T.O. 85 minutes) predominated in the competitive season microcycle. Additionally, players spent 61 minutes performing soccer specific aerobic drills. Most drills came from training means groups number: 14 (championship games), 13 (small-sided games) and 11 (individual and group technical skill drills). Similar time of general and specific warm-up was noted. Relaxing, flexibility exercises and stretching $(21 \mathrm{~min})$ were usually performed as active recovery between or after games and exercises. A small scale of speed ( $2 \mathrm{~min})$ and strength (1 min) development occurred during the analyzed microcycle as well.

Tab. 3. Training unit 1 of the competitive season microcycle

\begin{tabular}{|c|c|c|c|c|c|c|}
\hline \multicolumn{7}{|c|}{ Training unit 1, Monday 07.09.2009, $16.00-17.30$} \\
\hline No & Drill type & $\begin{array}{l}\text { Effective time } \\
\text { (min) }\end{array}$ & $\begin{array}{c}\text { Total time } \\
(\min )\end{array}$ & $\begin{array}{c}\text { Energy- } \\
\text { information } \\
\text { field }\end{array}$ & $\begin{array}{c}\text { Drill intensity } \\
(\%)\end{array}$ & $\begin{array}{c}\text { General } \\
\text { effectiveness } \\
(\%)\end{array}$ \\
\hline 1. & Coordination drills & 12 & 15 & TO & 60 & 80 \\
\hline 2. & Stretching drills & 5 & 5 & TO & 30 & 100 \\
\hline 3. & Speed drills & 1 & 10 & BNKO & 100 & 10 \\
\hline 4. & Passing and reception drills & 12 & 15 & TS & 60 & 80 \\
\hline 5. & Dribbling drills & 12 & 15 & TS & 70 & 80 \\
\hline 6. & Small-sided game $7 \times 7$ & 20 & 25 & MS & 80 & 80 \\
\hline 7. & Relaxation drills & 2 & 5 & TO & 30 & 40 \\
\hline & A & 64 & 90 & \multicolumn{2}{|c|}{ REST TIME } & $26 \mathrm{~min}$ \\
\hline
\end{tabular}


A typical microcycle in the transition period was made up of five training units (Monday - two units; Wednesday, Friday and Saturday - one unit). Sample values of training loads are shown in Tables 6, 7 and 8.

General aerobic drills (140 minutes) predominated in the transition period microcycle. Less mixed special aerobic-anaerobic drills $(50 \mathrm{~min})$ and special aerobic drills $(37 \mathrm{~min})$ than in the competitive season microcycle occurred. Most drills came from training means number: 10 (supplementary sports), 13 (small-sided games), 11 (individual and group technical skill drills). The analyzed microcycle included 35 minutes of continuous running as well. Values of general and specific warm-ups, relaxing and flexibility exercises, strength and speed exercises in two analyzed microcycles were comparable.

The ratio of general drills to soccer-specific drills differed considerably in the two microcycles. The general means amounted to $57 \%$ in the transition period microcycle, while they reached $30 \%$ in the competitive season microcycle (see Figure 1). The phenomenon is widely described in the literature of the subject $[8,16]$.

Tab. 4 Training unit 2 of the competitive season microcycle

\begin{tabular}{|c|c|c|c|c|c|c|}
\hline \multicolumn{7}{|c|}{ Training unit 2, Wednesday $09.09 .2009,16.00-17.30$} \\
\hline No & Drill type & $\begin{array}{l}\text { Effective } \\
\text { time (min) }\end{array}$ & $\begin{array}{l}\text { Total time } \\
\quad(\min )\end{array}$ & $\begin{array}{c}\text { Energy- } \\
\text { information } \\
\text { field }\end{array}$ & $\begin{array}{c}\text { Drill } \\
\text { intensity } \\
(\%)\end{array}$ & $\begin{array}{c}\text { General } \\
\text { effectiveness } \\
(\%)\end{array}$ \\
\hline 1. & Warm-up with soccer balls & 12 & 15 & TO & 60 & 80 \\
\hline 2. & Stretching drills & 5 & 5 & TO & 30 & 100 \\
\hline 3. & Explosive strength drills & 1 & 10 & BNKO & 100 & 10 \\
\hline 4. & Shooting drills & 8 & 15 & TS & 60 & 60 \\
\hline 5. & $1 \times 1$ game & 7 & 15 & MS & 80 & 40 \\
\hline 6. & Small-sided game (aim: retaining ball possession) & 20 & 25 & MS & 80 & 80 \\
\hline 7. & Relaxation drills & 2 & 5 & TS & 30 & 40 \\
\hline & A & 55 & 90 & REST & IME & $35 \mathrm{~min}$ \\
\hline
\end{tabular}

Tab. 5 Training unit 3 of the competitive season microcycle

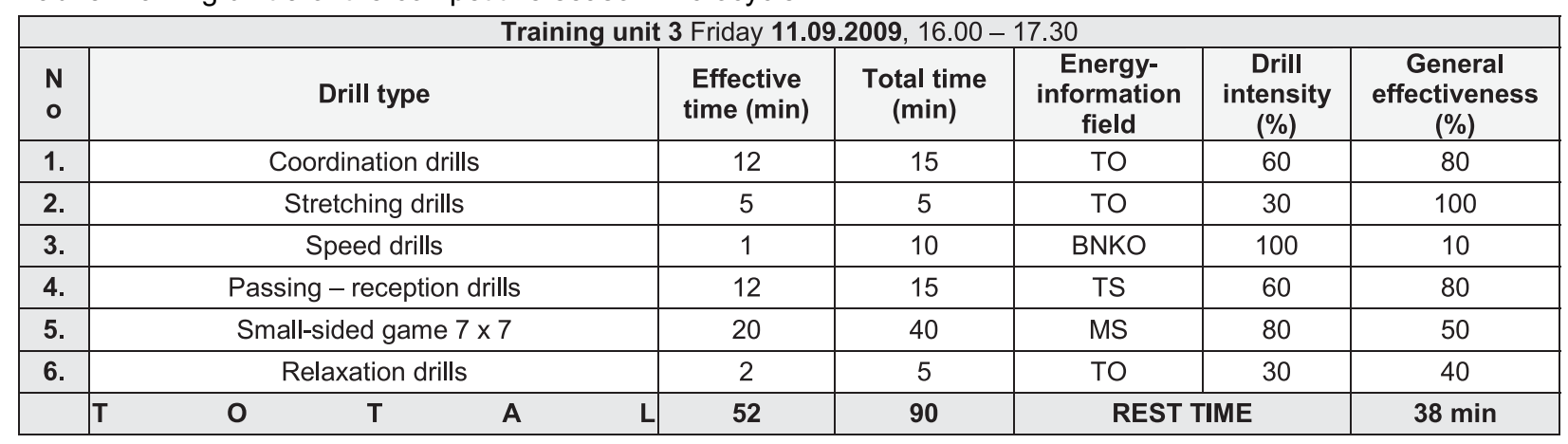

Tab. 6. Training unit 1 of the transition period microcycle

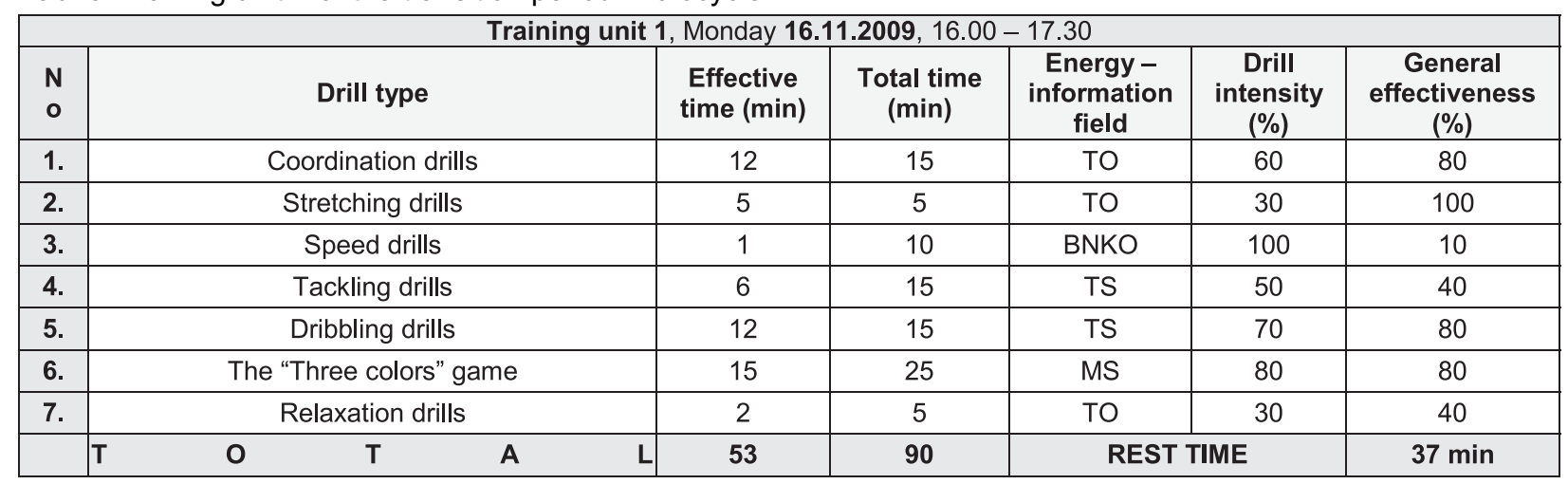


Tab. 7. Training unit 2 of the transition period microcycle

\begin{tabular}{|c|c|c|c|c|c|c|}
\hline \multicolumn{7}{|c|}{ Training unit 2, Wednesday $18.11 .2009,16.00-17.30$} \\
\hline No & Drill type & $\begin{array}{l}\text { Effective } \\
\text { time (min) }\end{array}$ & $\begin{array}{l}\text { Total time } \\
\quad(\min )\end{array}$ & $\begin{array}{c}\text { Energy- } \\
\text { information } \\
\text { field }\end{array}$ & $\begin{array}{c}\text { Drill } \\
\text { intensity } \\
(\%) \\
\end{array}$ & $\begin{array}{c}\text { General } \\
\text { effectiveness } \\
(\%) \\
\end{array}$ \\
\hline 1. & Warm-up with soccer balls & 12 & 15 & TS & 60 & 80 \\
\hline 2. & Stretching drills & 5 & 5 & TO & 30 & 100 \\
\hline 3. & Aerobic endurance drills & 15 & 20 & TO & 100 & 10 \\
\hline 4. & Shooting drills & 5 & 15 & TS & 60 & 60 \\
\hline 5. & Feint drills with a ball & 5 & 15 & MS & 80 & 40 \\
\hline 6. & Small-sided games (aim: retaining ball possession) & 10 & 15 & MS & 80 & 80 \\
\hline 7. & Relaxation drills & 2 & 5 & TO & 30 & 40 \\
\hline & A & 54 & 90 & REST & IME & $36 \mathrm{~min}$ \\
\hline
\end{tabular}

Tab. 8. Training unit 3 of the transition period microcycle

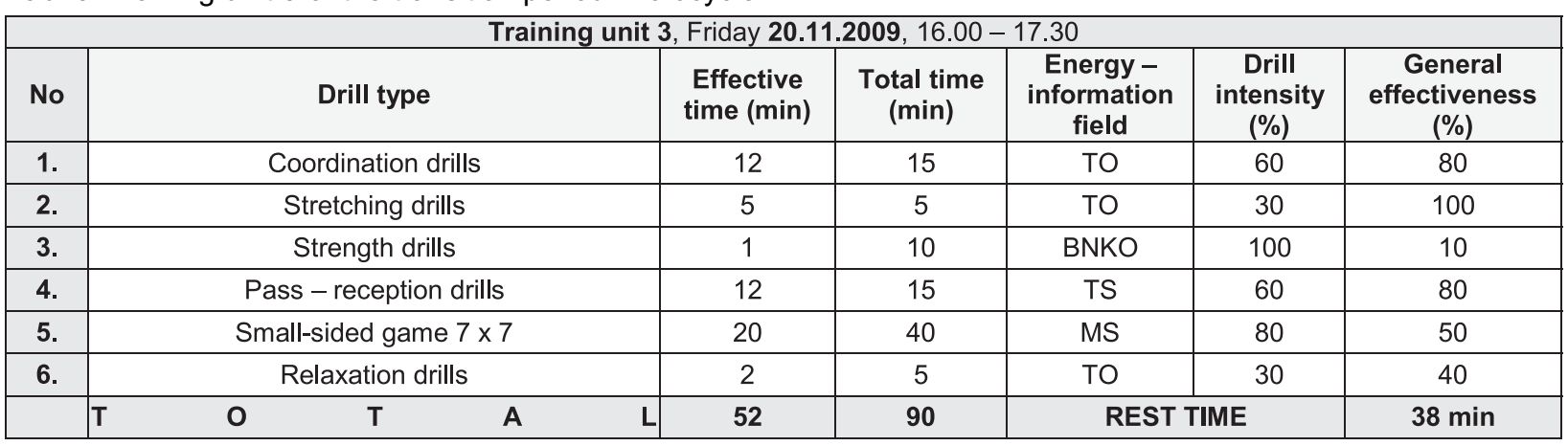

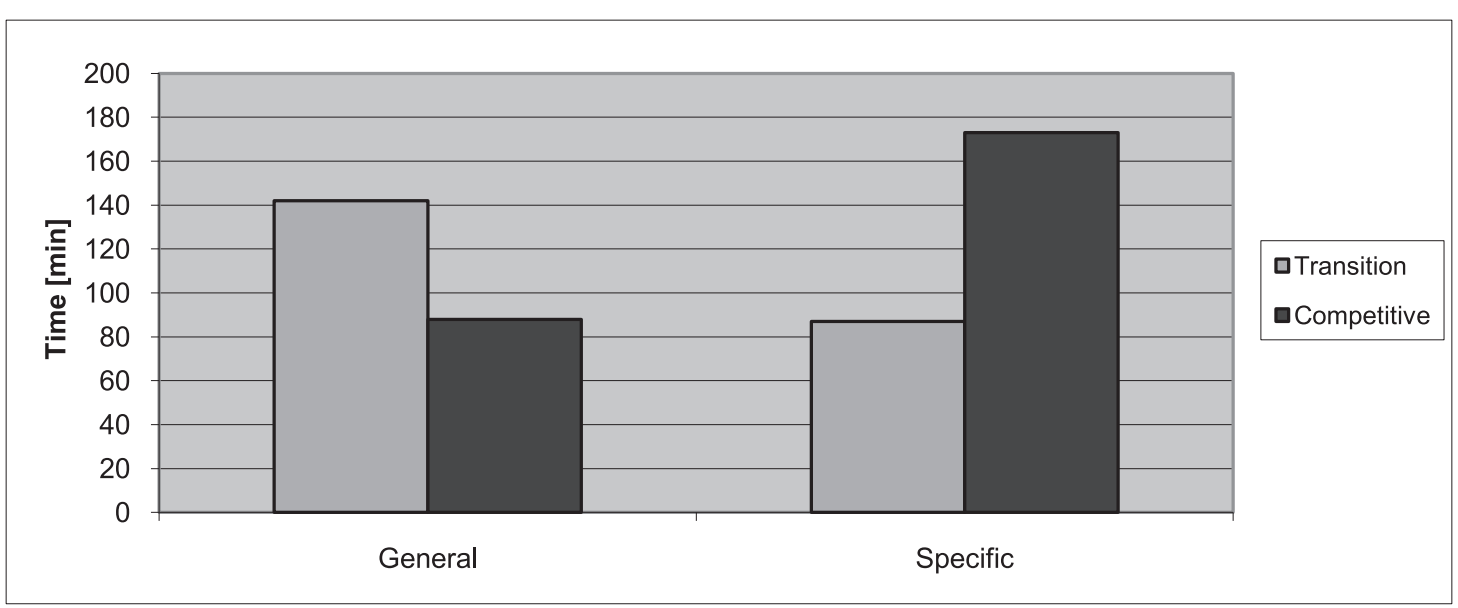

Fig. 1. Volume of the information field of the training load during the transition and competitive seasons applied to young soccer players

A typical transition period microcycle was predominated by aerobic drills (177 $\mathrm{min})$. Mixed anaerobic-aerobic drills (50 $\mathrm{min}$ ) and anaerobic non-lactate drills (2 $\mathrm{min}$ ) followed next. Although a typical microcycle during the competitive season was also predominated by aerobic performance $(131 \mathrm{~min})$, more time was allocated to mixed aerobic-anaerobic drills (127 minutes) and anaerobic non-lactate drills (3 minutes) (see Figure 2). The loads applied in the training practice correspond to common theories of soccer coaching.

During a typical microcycle of the transition period supplemental sports and general fitness exercises took 50 minutes, small-sided games took 45 minutes, individual and group technical drills took 40 minutes.

A close study of the competitive season microcycle reveals a great diversity of means applied in the training process. The ones most frequently used were: individual and group technical drills 


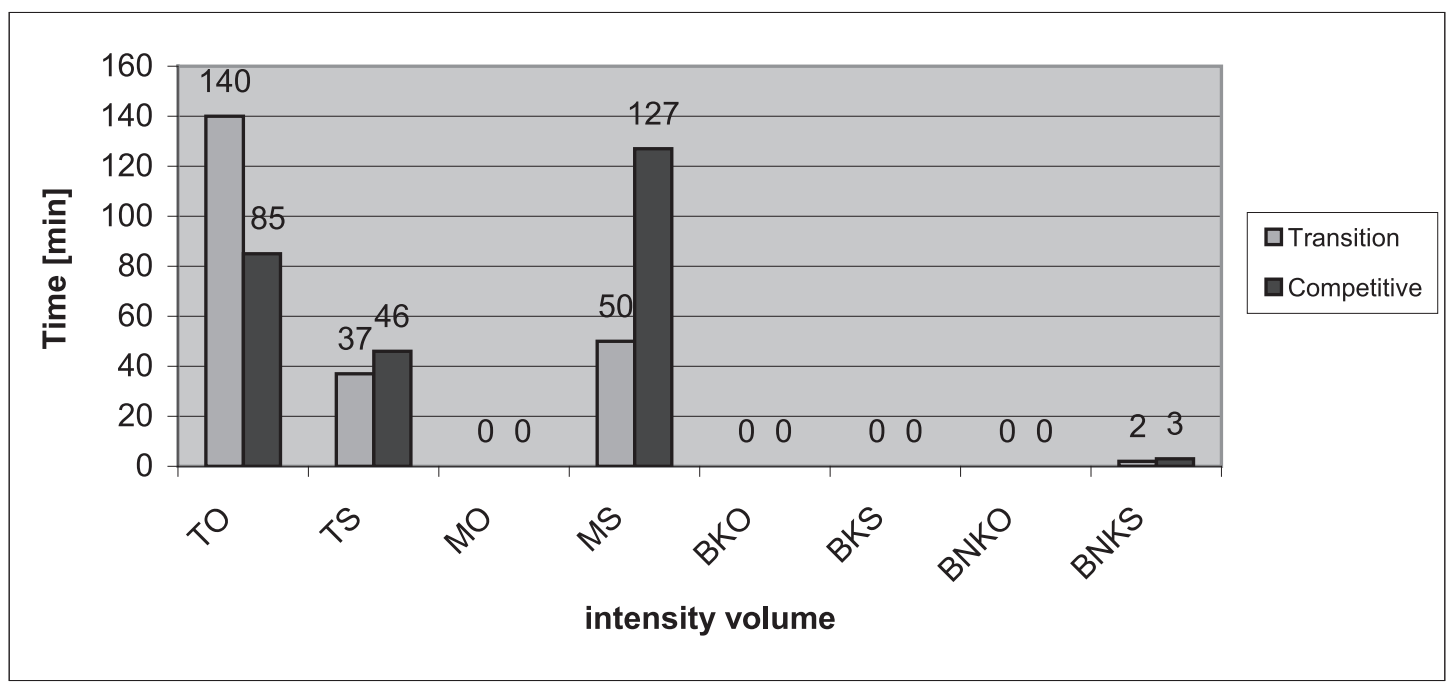

Fig. 2. Values of the general and specific training load within each intensity zone in the transition and competitive seasons

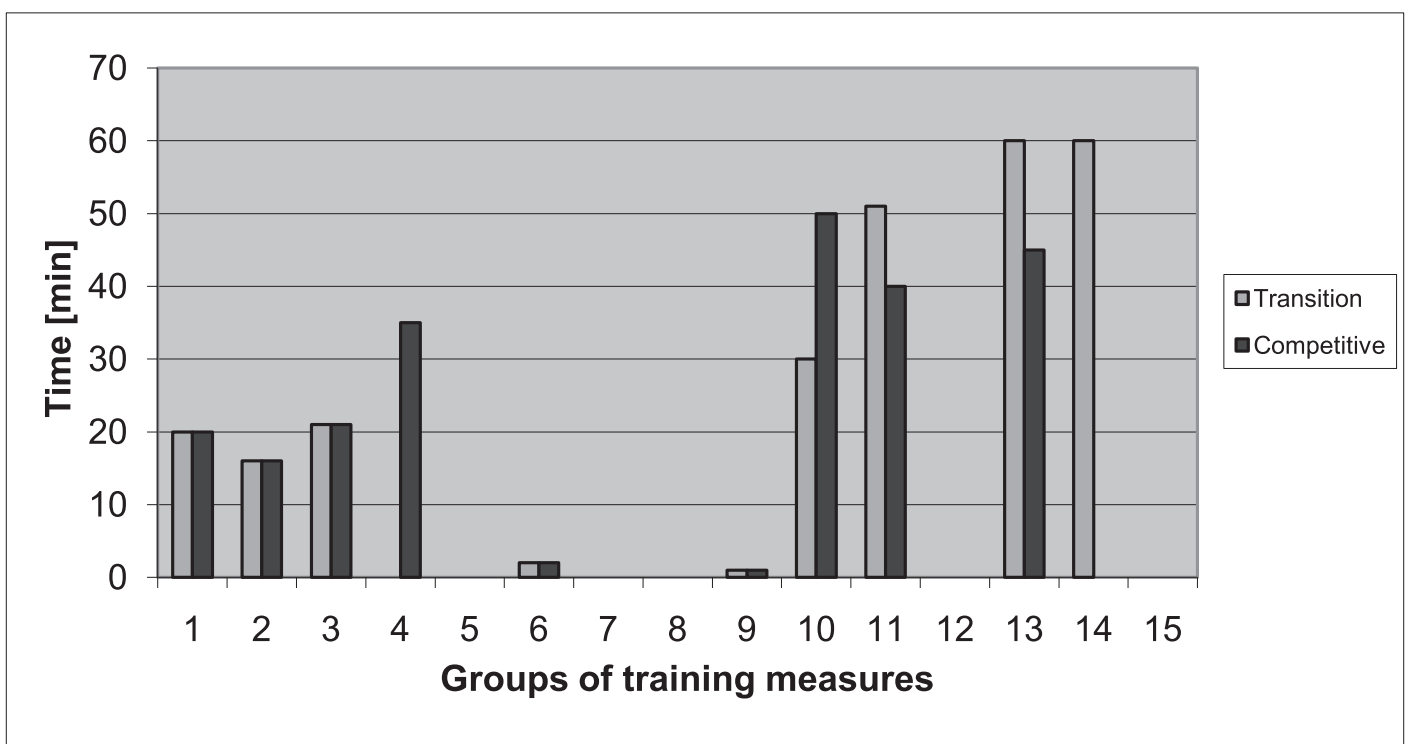

Fig. 3. Values of training means applied to young soccer players in typical microcycles of the transition and competitive seasons

(51 minutes) and championship games, which took as much time as small-sided games (60 minutes) (see Figure 3). The distribution of the applied training loads is in line with the most modern coaching trends.

\section{Discussion}

The results of this study show that there are obvious differences between range, quality and amount of training means in competitive and transition periods. The overall effective training time during the competitive season microcycle was 276 minutes and 229 minutes during the transition period. The training process during the starting season included more soccer-specific games, and more exercises at mixed aerobic-anaerobic intensity occurred. During a typical microcycle of the transition period players performed more continuous running and general fitness exercises in form of different games and additional sports than in the competitive season (35 min vs 0 min 
and 50 min vs 30 min respectively). Additionally, general exercises at aerobic intensity occurred more often after the season (140 min vs $85 \mathrm{~min}$ ).

Monitoring the training process is considered to be crucial in soccer coaching. Thus a training load and the means of its registration constitute its significant element. A close analysis allows optimization of the training process and contributes to the players' harmonious development. Moreover, the possibility of comparing the recorded load with the theoretical models in literature and the results achieved by other teams seems to be a great asset as well.

The volume of the training load applied to LKS „Żuławy” Nowy Dwór Gdański players proves comparable with that of Lechia Gdansk soccer players' administered by Jastrzębski [16], and Jastrzębski and Szutowicz [14]. The range of the training load registered in the competitive season is in line with other authors' research $[17,18]$ where league matches and small-sided games were used particularly often.

It is stated in the study that considering the information field - specific drills (58.2\%), and considering energy systems - aerobic drills (36\%) predominated in the training practice. In regard to the training means of the competitive season most of them were realized as small-sided games in form of simplified games and free games than general drills and practice matches. Konieczna et al. [9] achieved similar results in the tests carried out in young players of Soccer Academy in Malbork. The study confirms that specific drills predominated in the competitive season $(53 \%)$. Plenty of time was devoted to practice and championship matches as well as to general drills and individual and group technical drills.

The ability to monitor training is critical to the process of quantization training and periodization plans [19]. Training load registration is the most important issue of training control though still underestimated by many coaches. The issue should be of close interest not only for professional soccer teams' coaches but particularly those inexperienced, working with young players. Choosing the optimal training load without previous observation and analysis of the recorded load poses a significant problem. The authors suggest that the registration method modified by Jastrzębski [9] makes a very good proposal not only for professional coaches but particularly for the novice ones.

The issue of training load application in young soccer players in the literature of the subject is limited due to the lack of a consistent training system and one registration method in Poland. Coaches rarely undertake the task of regular training load registration followed by a close analysis of data. The authors hope that the article proves instrumental in filling the information gap as well as helpful in practical use.

\section{Conclusion}

Range of training load registered in the competitive season is in line with other authors' research where league matches and small-sided games were used particularly often. The studied microcycles in the competitive season can be model ones and can be used in the training process of young football players.

\section{References}

1. McGuigan MR, Foster C. A new approach to monitoring resistance training. Strength Cond 2004;26(6):42-7.

2. Eniseler N. Heart rate and blood lactate concentrations as predictors of physiological load on elite soccer players during various soccer training activities. J Strength Cond Res 2005;19(4):799-804.

3. Dellal A, Chamari K, Pintus A, Girard O, Cotte T, Keller D. Heart rate responses during small-sided games and short intermittent running training in elite soccer players: a comparative study. J Strength Cond Res 2008;22(5): 1449-1457.

4. Foster CD, Twist $\mathrm{C}$, Lamb KL, Nicholas $\mathrm{CW}$. Heart rate responses to small-sided games among elite junior rugby league players. J Strength Cond Res 2001;24(4):906-911.

5. Dellal A, Keller D, Carling C, Chaouachi A, Wong DP, Chamari K. Physiologic effects of directional changes in intermittent exercise in soccer players. J Strength Cond Res 2010;24(12):3219-26.

6. Wolkow NM, Koriagin WN. Z badań nad kryterium obciążeń treningowych [in Polish] [Of research on a criterion of training loads]. Sport Wyczynowy 1977;7:11-16. 
7. Kosendiak J, Łasiński G. Systemowe podstawy programowania treningu sportowego [in Polish] [System basics of the sports training programming]. Sport Wyczynowy 1987;8-9:19-33.

8. Sozański H, Śledziewski D. Obciążenia treningowe - dokumentowanie i opracowywanie danych [in Polish] [Training loads - documentation and data working out]. Warszawa: RCM-SzKFiS; 1995.

9. Jastrzębski Z. Obciążenia treningowe w piłce nożnej-modyfikacje ich rejestracji [in Polish] [Training loads in soccer]. In: Stuła A, editor. Wybrane zagadnienia treningu sportowego piłkarzy nożnych [Chosen problems of sports training in soccer]. Gorzów Wlkp.; 2005, 49-58.

10. Brink S, Nederhof E, Visscher C, Schmikli SL, Lemmink KAPM. Monitoring load, recovery, and performance in young elite soccer players. J Strength Cond Res 2010;24(3):597-603.

11. Stagno KM, Thatcher R, van Someren KA. A modified TRIMP to quantify the in-season training load of team sport players. J Sports Sci 2007;25:629-634.

12. Impellizzeri FM, Rampinini E, Coutts AJ, Sassi A, Marcora SM. Use of RPE-based training load in soccer. Med Sci Sports Exerc 2004;36:1042-1047.

13. Konieczna A, Barnat W, Ziemnicka M, Jastrzębski Z. Obciążenia treningowe a zmiany wybranych wskaźników antropometrycznych młodych piłkarzy nożnych na etapie ukierunkowanego szkolenia [in Polish] [Training loads vs changes of chosen anthropometrical indices inthe directed-training level]. Rocznik Naukowy /AWFiS/ 2009;XIX:29-34.

14. Jastrzębski Z, Szutowicz M. Obciążenia treningowe a poziom wydolności fizycznej piłkarzy nożnych na etapie ukierunkowanego szkolenia [in Polish] [Training loads vs level of physical capacity in soccer players at the directed stage of training]. In: Stuła A, editor. Wybrane zagadnienia treningu sportowego piłkarzy nożnych [Chosen problems of sports training in soccer]. Gorzów Wlkp.; 2005, 59-70

15. Śliwowski R, Jóźwiak J, Pietrzak M, Wieczorek A, Wieczorek J. Aerobic performance of young soccer players in the preparatory period. Studies in Physical Culture and Tourism 2007;14:293-297.

16. Jastrzębski Z. Zakres obciążeń treningowych w piłce nożnej i ręcznej a ich wpływ na rozwój sportowy zawodników [in Polish] [Scope of training loads in soccer and handball and their influence on competitors' sports development]. Gdańsk: AWFiS, 2005.

17. Szwarc A. Zmiany struktury obciążeń treningowych w 3-letnim cyklu szkolenia młodych piłkarzy nożnych [in Polish] [Changes in training loads in a three-year cycle of training of young soccer players]. Sport Wyczynowy 2002;12:445-446.

18. Jastrzębski Z, Szwarc A. Struktura organizacyjna i jej wpływ na efektywność szkolenia piłkarskiego na przykładzie Szkoły Mistrzostwa Sportowego w Gdańsku [in Polish] [Organization structure and its influence on the efficiency of training based on an example of Sports Masters' Secondary School in Gdansk]. Gdańsk: AWFiS, 2003.

19. Foster C, Florhaug JA, Franklin J, et al. A new approach to monitoring exercise training. J Strength Cond Res 2001;15(1):109-115. 